\title{
Assessing the Impact of Electricity Production on Industrial and Agricultural Output Growth in Nigeria
}

\author{
Imisi Aiyetan`, Adeleke Aremo*, Philip Olomola* \\ + School of Economic Sciences, Washington State University, Pullman, United States \\ * Department of Economics, Obafemi Awolowo University, Ile-Ife, Nigeria.
}

\begin{tabular}{l}
\hline ARTICLE INFO \\
\hline Article History \\
Received 17 November 2020 \\
Accepted 29 January 2021 \\
\hline JEL Classifications \\
Q40, Q30
\end{tabular}

Keywords:

Structural VAR

Industrial output,

Agricultural output,

Electricity production

\section{ABSTRACT}

Purpose:

While the relationships between energy or electricity consumption and economic growth are of great interest to economists, previous studies have not examined the dynamic effect of electricity production on industrial and agricultural output growth in Nigeria; this study attempts to fill the gap. This study thus investigates the dynamic effects of electricity production from renewable and non-renewable energy sources on industrial and agricultural output growth in Nigeria.

Design/methodology/approach:

This study disentangled electricity production by source - into renewable and nonrenewable - and employed a Structural Vector Autoregressive (SVAR) and other time series econometrics analysis.

\section{Findings:}

This study found that electricity production from both sources has a slight impact on the growth of the Nigerian industrial and agricultural sectors. In addition, this study supports the existing claim that economic growth and energy are linked and thus disproves the neo-classical assumption of the neutrality hypothesis.

Research limitations/implications:

This study considers annual data for all the variables due to the available data frequency for electricity production. However, the study assesses the validity of the estimated SVAR, and the results show that the analysis is robust for this study.

Originality/value:

This study contributes to the existing empirical literature by disentangling electricity production into renewable and non-renewable- and then examine their impacts on the crucial sectors of the Nigerian economy. This study shows that electricity production from the two energy sources contributes marginally to the growth of the industrial and agricultural sectors in Nigeria. Therefore, among other policy prescriptions, the author recommends that acceleration of projects that focus on off-grid electricity production under the Nigerian Energy Support Program (NESP) could minimize the current challenges of electricity production and its impact on the economy.

\section{Introduction}

As in many other countries, the challenges posed by an unreliable power supply in Nigeria threaten social and economic life in the face of surging population growth. The country grapples with an insufficient supply of energy, which adversely affects the quality of life of citizens both in urban and rural areas and limits inclusive growth. However, as utilities are a key component of economic, social and political development, a reliable energy supply that results in an improved standard of living is necessary (NEERP, 2015).

Nigeria is blessed with energy resources that include non-renewable energy sources (such as coal, oil and gas) and renewable energy sources (such as hydropower, sun, and wind). In particular, the main sources of on-grid electricity generation in Nigeria come from fossil fuel and hydropower. As of 2014, electricity production from oil, gas and coal accounted for $82.41 \%$ of the total electricity produced, with the remainder produced by hydropower (17.59\%) (World 
Bank, 2017). Over the years, the on-grid electricity generation in Nigeria has been based on fossil fuel and hydropower energy sources. The following analysis provides background information about fossil fuel and hydropower electricity generation in Nigeria.

\section{Hydropower}

Nigeria is endowed with large rivers and some natural falls, which are responsible for the high hydropower potential of the country. The Niger and Benue rivers and their tributaries constitute the core of Nigeria's river system, which offers a significant source of renewable energy including hydropower (greater than 100MW). Technically, the total exploitable scale of the hydropower potential of the country is estimated at over 14,120 MW, which is capable of producing over $50,800 \mathrm{GWh}$ of electricity annually. However, as of 2012 , only about $15 \%$ of the potential had been developed. The installed hydropower capacity is estimated to be 2,062 MW as of 2017 (International Hydropower Association (IHA), 2019).

\section{Fossil fuel}

As an OPEC nation, Nigeria possesses abundant oil and gas resources, which make the country the largest in Africa in terms of oil and gas reserves. As of 2018 , Nigeria's oil and gas reserve stood at 37 billion barrels and 192 trillion cubic feet respectively (OPEC, 2019). Likewise, coal reserves are estimated to be at least 2 billion metric tons; these reserves remain less exploited to date. With these vast fossil fuel-based reserves, as of 2016, the total electricity generated came from natural gas and was estimated to be 23.79 billion kilowatt-hours, an increase from 9.16 billion kilowatthours in 1997, with an average annual growth rate of 5.83 \% (Report: Knoema, 2016). The following diagrams show the state of on-grid electricity production in Nigeria:

\section{Energy Source from Nigeria's Natural Resources}

Renewable Energy Sources
Falls and Rivers
Sun
Wind
Non -Renewable Energy Sources
Coal
Oil
Natural Gas

Source: Author's Compilation

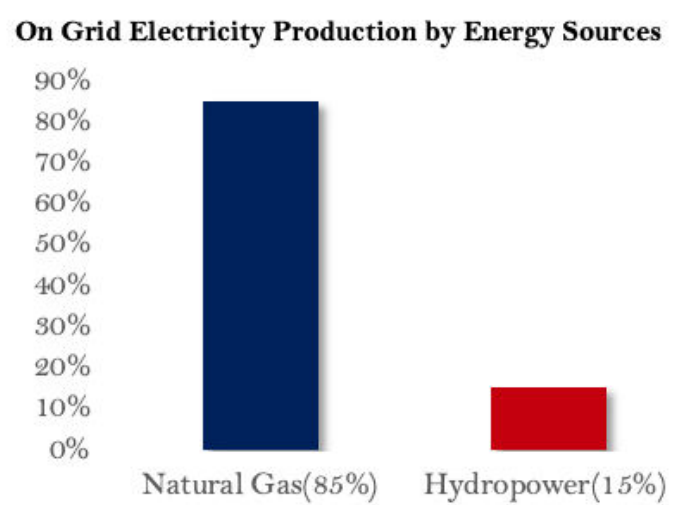

Source: Author's Compilation

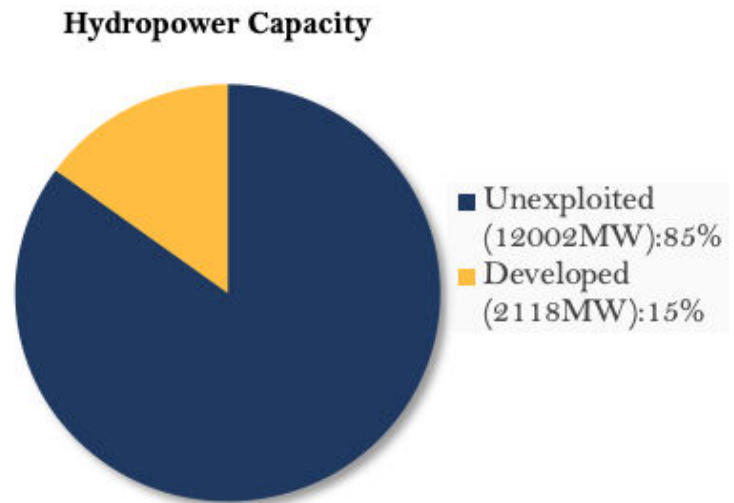

Source: International Hydropower Association, 2019

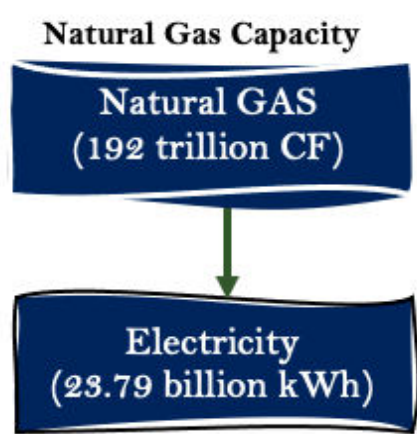

Source: Author's Compilation

Figure 1: State of on-grid electricity production in Nigeria

Despite the abundant renewable (hydropower) and non-renewable (fossil-fuel) energy resources, the Nigerian energy sector has yet to meet the electricity demand of the country, leading to the question of to what extent this impacts the economic development of the country. Therefore, it is important to establish whether or not electricity production from non-renewable and renewable energy sources contributed significantly to the industrial and agricultural output growth over the previous years. Hence, the study sought to empirically investigate the dynamic effects of electricity production from renewable and non-renewable energy sources on industrial and agricultural output growth in Nigeria. This study considers industrial and agricultural sectors due to their importance to the 
socio-economic development of the country. For instance, employment in industrial and agricultural sectors accounts for about $44.12 \%$ of total employment by economic activity (National Bureau of Statistics, 2010).

The results of the econometric analysis show that electricity production contributes marginally to the growth of the industrial and agricultural sectors in Nigeria. In addition, the results support the existing fact that energy and economic growth are linked. Therefore, as the shortage of electricity supply remains a threat to the growth of the Nigerian economy, the following are necessary: prioritization of policies for the development of the energy sector; eradication of mismanagement and lack of monitoring; diversification of electricity production across the potential energy sources; and acceleration of projects under the NESP.

The remainder of the paper is organized as follows: after the introductory section, section 2 provides a review of the literature. Section 3 describes the data handling and sources, the econometrics model and the empirical methods. Section 4 reports the empirical results and discussion. Section 5 concludes the study and offers pertinent policy prescriptions.

\section{Review of Literature}

To a large extent, the nexus between electricity generation from renewable and non-renewable energy resources and economic activity has long been a subject of impressive argument in the literature. Empirical evidence shows diverse relationships. In studies of the relationships between renewable and non-renewable electricity generation and economic activities, several studies have found bidirectional causality of these variables (i.e., power generation stimulates economic activities, vice versa) (Apergis and Payne, 2011; Ohler and Fetters, 2014; among others), unidirectional causality (Akinlo, 2009; Ackah, 2015; Cerdeira Bento and Moutinho, 2016; among others ), and positive relationship (Al-mulali et al. 2014; among others ).

Ohler and Fetter (2014) found a bidirectional relationship between aggregate renewable generation and real gross domestic product (GDP) in 20 OECD Countries. On the other hand, Marques et al. (2014) found no evidence of causal relationships between renewable electricity to economic growth but economic growth gives rise to renewable electricity. Al-mulali et al. (2014) showed that both renewable electricity consumption and non-renewable electricity consumption have a long-run positive effect on GDP growth in 18 Latin American Countries and all the three variables have a feedback causal relationship. In support of Al-mulali et al (2014) and Ohler and Fetter (2014), Dogan (2015) found that in the long-run, there is a bidirectional relationship between renewable and non-renewable electricity consumption and economic growth in Turkey (i.e., supports the feedback hypothesis in the long-run). On the other hand, Cerdeira Bento and Moutinho (2016) findings disagreed with those of Dogan (2015). They found that there is unidirectional causation running from output to renewable electricity production in Italy.

Apergis and Payne (2009) found bidirectional causality between electricity consumption and economic growth in both the short-run and long-run for 88 Countries. Unlike the findings of Apergis and Payne (2009), Tiwari et al (2014) argued that there is no long-run relationship between renewable energy production and economic growth in sub-Sahara African Countries. Considering recent studies, Maji, Sulaiman, and Abdul-Rahim (2019) found that energy consumption slowed down economic growth in 15 West African Countries. On the other hand, Rahman (2020) argued that there is unidirectional causality from economic growth to energy consumption in the 10 most electricityconsuming Countries. Using panel data for 174 Countries, Atems and Hotaling (2018) reported that there is a positively strong significant relationship between renewable and non-renewable electricity generation and growth. The authors also argued that electricity generation is more important than consumption since consumption is determined by distribution and transmission, which are largely affected by distribution theft and loss.

The existing empirical studies on Nigeria and West Africa have focused on the relationship between renewable and non-renewable energy consumption and economic growth (Ackah, 2015; Maji Sulaiman and Abdul-Rahim, 2019; Tiwari et al., 2014) and few empirical studies have examined the relationship between electricity consumption and economic growth ( Akinlo, 2009; Iyke, 2015; among others ). Akinlo (2009) found unidirectional Granger causality running from electricity consumption to real GDP in Nigeria. In support of Akinlo (2009), Iyke (2015) reported unidirectional causality running from electricity consumption to economic growth in both the short-run and long-run. In the same vein, Odugbesan and Husam (2020) revealed that there is unidirectional causality from energy consumption to economic growth in the case of energy-growth nexus in Nigeria. On the other hand, Ackah (2015) disagreed with Akinlo (2009) and Iyke (2015), showing that there is a long-run unidirectional causality from nonrenewable energy to growth in Ghana and a bidirectional relationship in Algeria and Nigeria. Nathaniel and Festus (2020) also found that electricity consumption increases economic growth in Nigeria.

To the best of our knowledge, the gap in the literature surveyed shows that many of these results are inconsistent with the reality in the case of Nigeria for the followings reasons:

Electricity consumption in Nigeria includes off-grid electricity consumption, which is generated by businesses or private individuals due to the failure of the government to meet energy demand. As argued by previous authors (Atems and Hotaling, 2018; Depuru et al.,2011; Jamil 2013; among others,), electricity production is more important than consumption since consumption is determined by distribution and transmission of electricity coming from production, both of which are largely affected by distribution theft and loss to weak infrastructure. Hence, it is crucial to establish whether or not electricity production from non-renewable and renewable energy sources drive the growth of the industrial and agricultural sectors. 


\section{Material and Methods}

\subsection{Data}

The dataset for this study covers the period 1981-2013 and was selected depending on the availability of data. This study has a total of 33 years of annual data. The dataset for natural resources indicators is defined as electricity production from hydroelectric sources (which represents electricity production from renewable energy) and electricity production from oil, gas and coal sources (which represents electricity production from non-renewable energy). The data are expressed in total percentages. Sectoral outputs are defined as industrial and agricultural outputs at 1999 constant basic price (N'Billion). All data were retrieved from the World Development Indicator (WDI) database (2015) and the Central Bank of Nigeria (2015) and are described in Table 1.

Table 1. Unit and Explanation of Statistical Data

\begin{tabular}{|c|c|c|c|}
\hline Variables & Units & Explanation & Source \\
\hline $\begin{array}{l}\text { Electricity } \\
\text { production } \\
\text { from oil, gas } \\
\text { and coal } \\
\text { sources }\end{array}$ & $\%$ of total & $\begin{array}{l}\text { Oil refers to crude oil and oil products. Gas refers to } \\
\text { natural gas but excludes natural gas liquids. Coal refers } \\
\text { to all coal and brown coal, both primary (including } \\
\text { patent fuel, coke oven coke, gas coke, coke oven gas and } \\
\text { blast furnace gas). }\end{array}$ & $\begin{array}{l}\text { World Bank Database } \\
\text { (World Development } \\
\text { Indicator) }\end{array}$ \\
\hline $\begin{array}{l}\text { Electricity } \\
\text { production } \\
\text { from } \\
\text { hydroelectric } \\
\text { sources }\end{array}$ & $\%$ of total & $\begin{array}{l}\text { Hydropower refers to electricity produced by } \\
\text { hydroelectric power plants. }\end{array}$ & $\begin{array}{l}\text { World Bank Database } \\
\text { (World Development } \\
\text { Indicator) }\end{array}$ \\
\hline $\begin{array}{l}\text { Industrial } \\
\text { Output }\end{array}$ & $\begin{array}{l}1990 \text { Constant } \\
\text { Basic Prices (N' } \\
\text { Billon) }\end{array}$ & $\begin{array}{l}\text { Industrial output refers to the total output of all the } \\
\text { facilities producing goods within a country e.g. crude } \\
\text { petroleum, natural gas, solid minerals and } \\
\text { manufacturing. }\end{array}$ & $\begin{array}{l}\text { Central Bank of Nigeria } \\
(\mathrm{CBN})\end{array}$ \\
\hline $\begin{array}{l}\text { Agricultural } \\
\text { output }\end{array}$ & $\begin{array}{l}1990 \text { Constant } \\
\text { Basic Prices (N' } \\
\text { Billon) }\end{array}$ & $\begin{array}{l}\text { Agricultural output refers to the total output of crop, } \\
\text { forestry, fishing and livestock products }\end{array}$ & $\begin{array}{l}\text { Central Bank of Nigeria } \\
(\mathrm{CBN})\end{array}$ \\
\hline
\end{tabular}

\subsection{Observation}

The descriptive statistics of the series used in this study are detailed in Table 2. The results show that the standard deviations for both renewable and non-renewable electricity production, industrial output and agricultural output are quite low, implying that the data are evenly dispersed around the mean; the statistics by Jarque-Bera show that all the variables are normally distributed with zero mean and finite covariance.

Table 2. Summary of descriptive statistics of the variables

\begin{tabular}{lrrrrrrrr}
\hline Variables & Average & Median & Skewness & \multicolumn{1}{l}{ Kurtosis } & SD & Min & Max & JB \\
\hline $\operatorname{lnREP}$ & 3.437039 & 3.496524 & -0.82405 & 2.858039 & 0.213359 & 2.912351 & 3.734448 & $3.762524(0.152398)$ \\
$\operatorname{lnNREP}$ & 4.219244 & 4.204684 & 0.315781 & 2.222071 & 0.089979 & 4.062770 & 4.401829 & $1.380561(0.501435)$ \\
$\ln$ IND & 5.100526 & 5.049438 & 0.197919 & 1.970348 & 0.450055 & 4.394187 & 5.900657 & $1.673198(0.433181)$ \\
$\ln$ AGR & 4.761117 & 4.761041 & -0.222144 & 1.837775 & 0.252790 & 4.280295 & 5.110930 & $2.128718(0.344949)$ \\
\hline
\end{tabular}

Note: SD is standard deviation, JB is Jarque-Bera and the values in parentheses are probabilities of JB. 
Table 3. Correlation Matrix

\begin{tabular}{cllll}
\hline Variables & $\ln R E P$ & $\ln$ NREP & $\ln$ IND & $\ln$ AGR \\
\hline $\ln R E P$ & 1.0000000 & & & \\
$\ln$ RREP & -0.9875121 & 1.0000000 & & \\
$\ln \mathrm{NND}$ & -0.4549090 & 0.394527 & 1.0000000 & \\
$\ln \mathrm{AGR}$ & -0.2911690 & 0.240681 & 0.944211 & 1.00000000 \\
\hline
\end{tabular}

The pair-wise correlation results are reported in Table 3. The results show that industrial output and agricultural output are negatively correlated with renewable electricity production. Similarly, Non-renewable electricity production is inversely correlated with renewable electricity production. On the other hand, positive correlations are found between industrial output and non-renewable electricity production and between agricultural output and nonrenewable electricity production. Likewise, a positive correlation was reported between agricultural output and industrial output.

\subsection{Unit roots}

In this study, Augmented Dickey-Fuller (ADF), Phillip Perron (PP) and Zivot-Andrews (ZA) unit root tests were used to check for the stationarity of each variable. The main aim of a unit root test is to test whether time series are affected by transitory or permanent shocks. The ADF and PP unit root models are presented thus:

$$
\begin{gathered}
A D F: \Delta Y_{t}=\mu_{t}+\lambda t+\psi Y_{t-1}+\sum_{k-1}^{p} d_{k} \Delta Y_{t-k}+\varepsilon_{t} \\
P P: \Delta Y_{t}=\mu_{t}+\psi Y_{t-1}+\varepsilon_{t}
\end{gathered}
$$

Where $\Delta$ denotes the first difference, $\mathrm{y}_{\mathrm{t}}$ is the time series being tested, $\mathrm{t}$ is the time trend variable, and $\mathrm{p}$ is the number lag which is added to the model to ensure that the residual, $\varepsilon_{\mathrm{t}}$, is a disturbance term (i.e., it has zero mean and constant variance). The Schwarz information criterion (SIC) was used to determine the optimal lag length, p. In the equations above, we tested the null hypothesis of $\psi=0$ against the alternative hypothesis of $\psi<0$. Non-rejection of the null hypothesis implies that the series is non-stationary, whereas the rejection of the null hypothesis indicates the time series is stationary.

Many studies in the field of energy and natural resource economics in Nigeria have applied conventional unit root tests without checking if the presence of significant structural breaks in the deterministic trend renders the outcome of these conventional unit root tests biased (see, for example, Akinlo, 2009; Akpan and Akpan (2012); Ackah, 2015 among others). The motivation for a structural break in this study is that natural disaster affects electricity producing facilities, which could lead to a sudden break in electricity production. To consider the possible presence of a structural break in the time series data and strengthen the inference of this study, the Zivot-Andrews (ZA) unit root test, which accounts for a structural break, was adopted. The test utilizes the entire sample with different dummy variables for each possible break date (Zivot and Andrews, 1992).

The following regressions were used:

$$
\begin{aligned}
& \text { Model I: } \quad y_{t}=\mu+\theta D U_{t}\left(\tau_{b}\right)+\beta t+\alpha y_{t-1}+\sum_{i=1}^{k} \varphi_{i} \Delta y_{t-i}+e_{t}, \\
& \text { Model II: } y_{t}=\mu+\theta D T_{t}\left(\tau_{b}\right)+\beta t+\alpha y_{t-1}+\sum_{i=1}^{k} \varphi_{i} \Delta y_{t-i}+e_{t}, \\
& \text { Model III: } y_{t}=\mu+\theta D U_{t}\left(\tau_{b}\right)+\beta t+\lambda D T_{t}\left(\tau_{b}\right)+\alpha y_{t-1}+\sum_{i=1}^{k} \varphi_{i} \Delta y_{t-i}+e_{t},
\end{aligned}
$$

Where $D U_{t}\left(\tau_{b}\right)=1$ if $t>\tau_{b}$ and 0 otherwise; $D T_{t}\left(\tau_{b}\right)=t-\tau_{b}$ for $t>\tau_{b}$ and 0 otherwise; $\Delta$ is the first difference operator; and $e_{t}$ is a white noise disturbance term with variance $\sigma^{2} . D U_{t}$ is a sustained dummy variable that captures a shift in the intercept and $D T_{t}$ represents a shift in the trend occurring at time $\tau_{b}$. Model I includes the intercept; Model II includes the trend; and Model III captures the possibility of a change in both the intercept and trend.

\subsection{Cointegration test analysis}

The Johansen cointegration test was employed (Johansen, 1988; Johansen and Juselius, 1990). This test sets up the non-stationarity time series as a vector autoregression (VAR) of order $\mathrm{p}$ :

$$
\Delta Y_{t}=\sum_{t-1}^{p} \Gamma_{i} \Delta Y_{t-i}+\sum_{k-i}^{p} \Gamma_{k-i} \Delta Y_{t-k-i}+\prod Y_{t-1}+\mu_{t}
$$

Given that $Y_{t}$ is a vector of non-stationary $I(0)$ variables, then $\Delta Y_{t-1}$ are $I(1)$ and $\prod Y_{t-1}$ must be $I(0)$ in order to have $\mu_{t} \approx I(0)$ and therefore to have a well-behaved system. 
The trace test and the maximum eigenvalue test were used to test the hypothesized existence of the $r$ cointegrating vector. The trace test statistic describes the null hypothesis when the number of distinct cointegrating vectors is less than or equal to $r$. On the other hand, the maximum eigenvalue test statistic describes the null hypothesis when the number of cointegrating vectors is $r$ against the alternative of $r+1$ cointegrating vectors.

\subsection{Hatemi-J Threshold cointegration approach}

A cointegration test between variables with unit root is an integral part of empirical time series analyses. Most conventional cointegration tests (i.e. Engle and Granger (1987), Johansen and Juselius (1990) and Pesaran et al (2001)) assume that the cointegration vector remains the same during any period of study. There are many reasons to expect that the long-run relationship between variables might change (i.e. a shift in the cointegration vector can occur). Structural change can take place because of economic crises; technological shock; changes in the economic actors, preferences and behavior; policies and regime changes; and organizational or institutional evolution (Hatemi-J, 2008). Therefore, to identify the long-term relationship among the variables, this study also adopted the Hatemi-J cointegration test that accounts for two structural breaks through two possible regime shifts (i.e. regime changes endogenously with level and slope dummies). This model is defined as follows:

$$
y_{t}=\kappa+\delta^{\prime} x+u_{t}, \quad t=1,2, \ldots \ldots \ldots . . . n
$$

To account for the effect of two structural breaks on both the intercept and the slope (two regime shifts), equation 1 is generalized as follows:

$$
y_{t}=\kappa_{0}+\kappa_{1} D_{1 t}+\kappa_{2} D_{2 t}+\delta_{0}^{\prime} x_{t}+\delta_{1}^{\prime} D_{1 t} x_{t}+\delta_{2}^{\prime} D_{2 t} x_{t}+u_{t},
$$

Where $D_{t t}$ and $D_{2 t}$ are dummy variables defined as

$$
D_{1 t}=\left\{\begin{array}{l}
0^{i f}=t \leq\left[n \tau_{1}\right] \\
1_{\text {if }}=t>\left[n \tau_{1}\right]
\end{array}\right.
$$

and

$$
D_{2 t}=\left\{\begin{array}{l}
0 \text { if }=t \leq\left[n \tau_{2}\right] \\
1 \text { if }=t>\left[n \tau_{2}\right]
\end{array}\right.
$$

With the unknown parameters $\tau_{1} \in(0,1)$ and $\tau_{2} \epsilon(0,1)$ signifying the timing of the regime change point and the bracket denoting the integral part. To test the null hypothesis of no cointegration, the ADF test was calculated by the corresponding t-test for the slope of $\hat{u}_{t-1}$ in a regression of $\Delta \hat{u}_{t}$ on $\hat{u}_{t-1}, \Delta \hat{u}_{t-1}, \ldots, \Delta \hat{u}_{t-k}$, where $\hat{u}_{t}$ signifies the estimated error term from regression (2). The $Z_{\alpha}$ and $Z_{t}$ test statistics are based on the calculation of the biascorrected first-order serial correlation coefficient estimation.

\subsection{SVAR model and identification assumption}

The variables in this study are analyzed using SVAR approach and they are proxied as $\ln R E P_{t}, \ln N R E P_{t}, \ln I N D_{t}$ and $\ln A G R_{t}$ where $\ln I N D_{t}$ is the natural logarithm of industrial output growth; $\ln A G R_{t}$ is the natural logarithm of agricultural output; $\ln R E P_{t}$ is the natural logarithm of renewable electricity production; and $\ln N R E P_{t}$ is the natural logarithm of non-renewable electricity production. The structural representation of the VAR is given as follows:

$$
A Y_{t}=\sum_{i=1}^{p} \delta_{i} Y_{t-i}+\varepsilon_{t}
$$

where A denotes a contemporaneous coefficient matrix and $\varepsilon_{t}$ denotes a vector of serially and mutually uncorrelated structural shocks. The lag-length, $\mathrm{P}$, is determined based on the Akaike Information Criterion (AIC).

The reduced form of the structural representation of Eq. (9) is shown here:

$$
Y_{t}=\sum_{i=1}^{p} \lambda_{i} Y_{t-i}+B \varepsilon_{t}
$$

Where $\mathrm{B}=\mathrm{A}^{-1}, \lambda_{i}=A^{-1} \delta_{i}$. The prediction reduced form errors of $Y_{t}$, condition on the information contained in the vector of lagged endogenous variables $X_{t}=\left[Y_{t-1}{ }^{\prime}, \ldots, Y_{t-p}{ }^{\prime}\right]^{\prime}$ were used together with restrictions imposed on $B \varepsilon_{t}$ to obtain the structural shock, where elements of matrix $\mathrm{B}$ are known if the instantaneous relation between 
structural and reduced innovations is known. However, in this study, I used a short-run SVAR model (AB model) following Amisano and Giannini (1997). Therefore, (11) can be written as follows

$$
\begin{gathered}
A A(L) Y_{t}=A \varepsilon_{t}=B e_{t} \\
A \varepsilon_{t} \varepsilon_{t}^{\prime} A^{\prime}=B B^{\prime}
\end{gathered}
$$

Where $\mathrm{L}$ is the lag operator ; $\mathrm{A}, \mathrm{B}$ are $(n \times n)$ invertible matrices; $E\left(\varepsilon_{t}\right)=0$ and $E\left(\varepsilon_{t} \varepsilon_{t}{ }^{\prime}\right)=\sum ; E\left(e_{t}\right)=0$ and $E\left(e_{t} e_{t}{ }^{\prime}\right)=I_{k}$. The identifications were obtained by placing restriction on the matrices A and B as in (13), which the study assumed to be nonsingular. The orthogonalization matrix $\Pi=A^{-1} B$ is related to the error covariance matrix $\sum=\prod \prod^{\prime}$. Hence, given the symmetric nature of $\sum$, there are $K(K+1) / 2$ free parameters, although many parameters may be estimated in the matrices $\mathrm{A}$ and $\mathrm{B}$ as in $2 K^{2}$. However, the order of condition for identification requires $2 K^{2}-K(K+1) / 2$ restrictions be placed on the free elements of these matrices.

To impose the recursive structure the short-term restrictions, (11) can be constructed as matrix algebra as follows:

$$
\left[\begin{array}{cccc}
1 & 0 & 0 & 0 \\
a_{21} & 1 & 0 & 0 \\
a_{31} & a_{32} & 1 & 0 \\
a_{41} & a_{42} & a_{43} & 1
\end{array}\right]\left[\begin{array}{c}
\varepsilon_{\ln r e p} \\
\varepsilon_{\ln n r e p} \\
\varepsilon_{\ln i n d} \\
\varepsilon_{\ln a g r}
\end{array}\right]=\left[\begin{array}{cccc}
b_{11} & 0 & 0 & 0 \\
0 & b_{22} & 0 & 0 \\
0 & 0 & b_{33} & 0 \\
0 & 0 & 0 & b_{44}
\end{array}\right]\left[\begin{array}{c}
e_{\ln r e p} \\
e_{\ln n r e p} \\
e_{\ln \text { ind }} \\
e_{\ln \text { agr }}
\end{array}\right]
$$

Where $\varepsilon_{\mathrm{t}}=\left[\varepsilon_{\text {lnrep }}, \varepsilon_{\text {lnnrep }}, \varepsilon_{\text {lnind }}, \varepsilon_{\text {lnagr }}\right]^{\prime}$ is the vector of reduced form disturbances of four-dimensional VAR; $\mathrm{e}_{\text {Inrep }}, \mathrm{e}_{\text {Innrep }}, \mathrm{e}_{\text {lnind }}, \mathrm{e}_{\text {lnagr }}$ are mutually uncorrelated structural shocks; and $\mathrm{a}_{21}, \mathrm{a}_{31}, \mathrm{a}_{32}, \mathrm{a}_{41}, \mathrm{a}_{42}, \mathrm{a}_{43}, \mathrm{~b}_{11}, \mathrm{~b}_{22}, \mathrm{~b}_{33}$ and $b_{44}$ are the structural parameters. Finally, the study employed maximum likelihood approach via Newton Raphson analytic derivation to estimate the $\mathrm{AB}$ model. The value of the elements in (13) are reported in subsection 3.6 .

3.7 Multivariate causality analysis

After the long-run relationship between the variables was examined, the granger causality/block exogeneity Wald test was used to determine causality between the variables. If no cointegration between the series was found, then the VAR method was developed as follows:

$$
\left[\begin{array}{c}
\ln \text { rep }_{t} \\
\ln \text { nrep }_{t} \\
\ln \text { ind }_{t} \\
\ln \text { agr }_{t}
\end{array}\right]=\left[\begin{array}{c}
\varphi \\
\vartheta \\
\rho \\
\pi
\end{array}\right]+\left[\begin{array}{llll}
A_{11, n} & A_{12, n} & A_{13, n} & A_{14, n} \\
A_{21, n} & A_{22, n} & A_{23, n} & A_{24, n} \\
A_{31, n} & A_{32, n} & A_{33, n} & A_{34, n} \\
A_{41, n} & A_{42, n} & A_{43, n} & A_{44, n}
\end{array}\right]\left[\begin{array}{c}
\ln \text { rep }_{t-k} \\
\ln \text { nrep }_{t-m} \\
\ln \text { ind }_{t-p} \\
\ln \text { agr }_{t-q}
\end{array}\right]+\left[\begin{array}{c}
\mu_{1 t} \\
\mu_{2 t} \\
\mu_{3 t} \\
\mu_{4 t}
\end{array}\right]
$$

In Eq. (14), the existence of a significant relationship of the variables provides the evidence for the direction of causality. In this model, we have three relationships: unidirectional, bidirectional, and not causal.

\section{Empirical Results and Discussions}

\subsection{Unit root tests results}

The results of unit root tests with and without accounting for a structural break are reported in Tables 4 and 5 respectively. The results of augmented Dickey Fuller (ADF) and Philip Perron (PP) for the series with and without trends show that none of the variables at levels are stationary at the $5 \%$ significance level. For the first-order difference series, the statistics consistently indicate that all the variables are stationary at the $1 \%$ significance level. Hence, the results of unit root tests without structural breaks suggest that all the series are integrated of order one $\sqsubset$ I (1)]. 


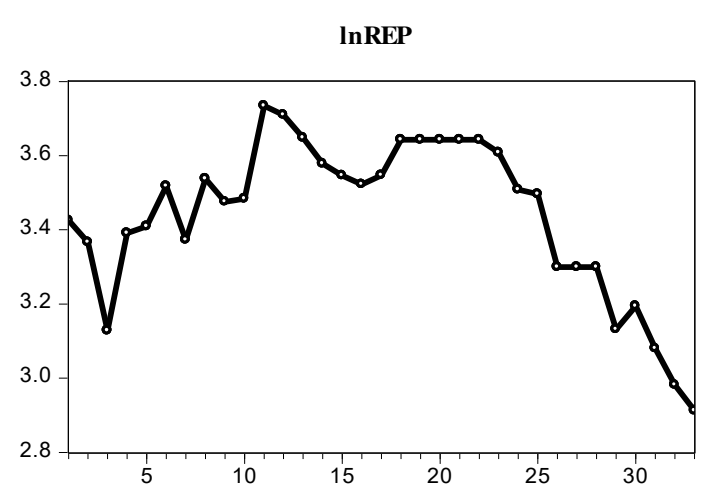

$\operatorname{lnNREP}$

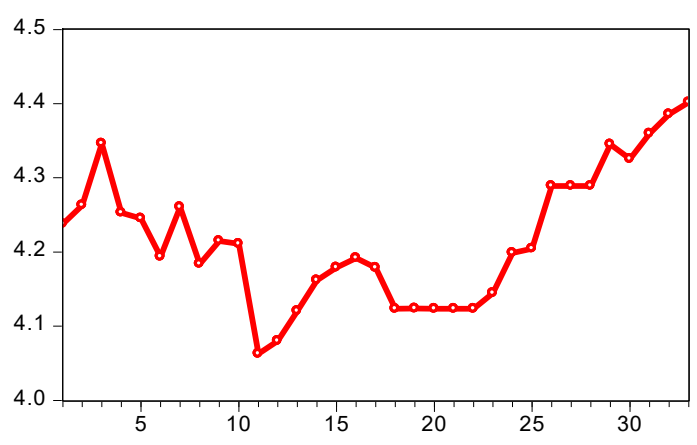

$\operatorname{lnIND}$
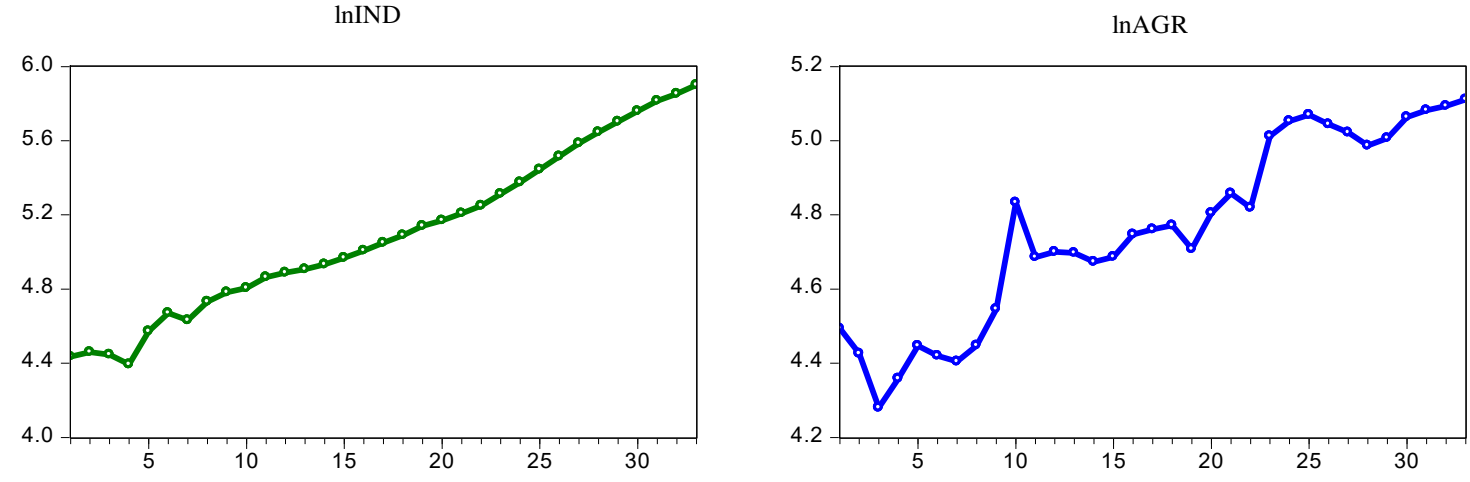

Figure 2: Variables in level

Table 4. Unit root analysis without structural break

\begin{tabular}{|c|c|c|c|c|}
\hline \multirow[t]{2}{*}{ Variables } & \multicolumn{2}{|c|}{ ADF Test } & \multicolumn{2}{|c|}{ PP Test } \\
\hline & Without Trend & With Trend & Without Trend & With Trend \\
\hline \multicolumn{5}{|l|}{ levels: } \\
\hline $\operatorname{lnREP}$ & -0.395028 & -0.936110 & -0.107841 & -0.477200 \\
\hline lnNREP & -0.872243 & -1.275401 & -0.791618 & -1.073577 \\
\hline $\operatorname{lnIND}$ & 1.543849 & -1.279067 & 0.800341 & -2.243043 \\
\hline $\ln A G R$ & -0.694562 & -3.554605 & -0.388631 & $-3.554605^{*}$ \\
\hline \multicolumn{5}{|c|}{ First differences: } \\
\hline$\Delta \mathrm{InREP}$ & $-6.774288^{*} * *$ & $-7.584907 * * *$ & $-6.743439 * * *$ & $-9.973032^{* * *}$ \\
\hline$\Delta \operatorname{lnNREP}$ & $-6.423337 * * *$ & $-3.764723^{* *}$ & $-6.432286^{* * * *}$ & $-8.522343^{* * *}$ \\
\hline$\Delta \ln I N D$ & $-5.884710^{* * * *}$ & $-5.981884^{* * * *}$ & $-5.898573^{*} * *$ & $-5.981884^{* * *}$ \\
\hline$\Delta \operatorname{InAGR}$ & $-6.055522^{* * * *}$ & $-5.940918^{* * *} *$ & $-7.454738 * * *$ & $-7.225411^{* * *}$ \\
\hline
\end{tabular}

*, ** and *** indicate significant at the $10 \%, 5 \%$ and $1 \%$ respectively.

Table 5. Zivot and Andrew's structural break unit root test

\begin{tabular}{|c|c|c|c|c|c|}
\hline Variables & Test & t-statistic & $1 \%$ Critical value & Break year & $\begin{array}{r}\text { Lag } \\
\text { length }\end{array}$ \\
\hline \multirow[t]{3}{*}{$\operatorname{lnREP}$} & $\mathrm{C}$ & -1.683480 & -5.34000 & 2006 & 4 \\
\hline & $\mathrm{T}$ & -3.509503 & -4.80000 & 2002 & 4 \\
\hline & $\mathrm{C} / \mathrm{T}$ & -3.367889 & -5.57000 & 2001 & 4 \\
\hline \multirow[t]{3}{*}{$\operatorname{lnNREP}$} & $\mathrm{C}$ & -2.697204 & -5.34000 & 2006 & 4 \\
\hline & $\mathrm{T}$ & -3.978229 & -4.80000 & 2001 & 4 \\
\hline & $\mathrm{C} / \mathrm{T}$ & -3.888137 & -5.57000 & 1991 & 4 \\
\hline \multirow[t]{2}{*}{$\operatorname{lnIND}$} & $\mathrm{C}$ & -2.245591 & -5.34000 & 2005 & 4 \\
\hline & $\mathrm{T}$ & -3.818242 & -4.80000 & 2002 & 4 \\
\hline
\end{tabular}




\begin{tabular}{|c|c|c|c|c|c|}
\hline \multirow{4}{*}{$\ln A G R$} & $\mathrm{C} / \mathrm{T}$ & -3.670063 & -5.57000 & 2000 & 4 \\
\hline & $\mathrm{C}$ & -4.519253 & -5.34000 & 1989 & 4 \\
\hline & $\mathrm{T}$ & -3.974500 & -4.80000 & 1991 & 4 \\
\hline & $\mathrm{C} / \mathrm{T}$ & -4.245238 & -5.57000 & 2003 & 4 \\
\hline \multirow[t]{3}{*}{$\Delta$ InREP } & $\mathrm{C}$ & -7.804221 & -5.34000 & 2004 & 4 \\
\hline & $\mathrm{T}$ & -6.376083 & -4.80000 & 2007 & 1 \\
\hline & $\mathrm{C} / \mathrm{T}$ & -6.674531 & -5.57000 & 1998 & 1 \\
\hline \multirow[t]{3}{*}{$\Delta \operatorname{lnNREP}$} & $\mathrm{C}$ & -7.129262 & -5.34000 & 1993 & 4 \\
\hline & $\mathrm{T}$ & -5.377409 & 4.80000 & 2007 & 1 \\
\hline & $\mathrm{C} / \mathrm{T}$ & -5.525713 & -5.57000 & 1993 & 1 \\
\hline \multirow[t]{3}{*}{$\Delta \operatorname{lnIND}$} & $\mathrm{C}$ & -7.328851 & -5.34000 & 2003 & 2 \\
\hline & $\mathrm{T}$ & -8.09780 & -4.80000 & 1994 & 2 \\
\hline & $\mathrm{C} / \mathrm{T}$ & -7.946097 & -5.57000 & 1996 & 2 \\
\hline \multirow[t]{3}{*}{$\Delta \mathrm{InAGR}$} & $\mathrm{C}$ & -6.103486 & -5.34000 & 2005 & 4 \\
\hline & $\mathrm{T}$ & -5.471369 & -5.34000 & 2006 & 1 \\
\hline & $\mathrm{C} / \mathrm{T}$ & -6.215096 & -5.57000 & 1991 & 1 \\
\hline
\end{tabular}

The unit root tests included an intercept $(C)$, a trend $(T)$, and both intercept and trend $(C / T)$. The null hypothesis was that the series has a unit root with a structural break in the intercept $(C)$, in the trend $(T)$ and in both intercept and trend $(C / T) . T h e$ table values were obtained from Zivot and Andrews (1992).

Similarly, the unit root without structural breaks generated misleading results in the presence of structural breaks. However, the results consistently suggest that all the variables with structural breaks at constant, trend, and constant and trend are integrated of order 1; thus, the series are stationary after the first difference. Nathanial and Festus (2020) found similar results in their study on electricity consumption, urbanization and economic growth in Nigeria.

\subsection{Cointegration tests results}

Since the variables are integrated of order one. That is, they are found to be I (1) processes, which support the theoretical basis that the variables are likely to move together in the long run when they drift apart in the short run. Then, to check for cointegration among variables, the study employed the Johansen cointegration test without structural breaks and the Hatemi-J threshold cointegration test with structural breaks. Table 6 reports the maximum eigenvalue statistics and trace statistics of Johansen's cointegration. The results of Johansen's cointegration test show that neither maximum eigenvalue statistics nor trace statistics reject the null hypothesis of the presence of a no cointegration relationship. This finding validates the conditions for using SVAR techniques.

Likewise, the results of Hatemi-J threshold cointegration with two breakpoint tests are reported in Table 7 . The modified $\mathrm{ADF}^{*}, \mathrm{Z}_{\mathrm{t}}^{*}$, and $\mathrm{Z} \alpha^{*}$ test statistics failed to reject the null hypothesis of no cointegration at the $5 \%$ level of significance. This finding implies that there is no cointegration relationship between the variables for two regime shifts. However, the timing of the structural breaks is endogenously determined.

Table 6. Johansen Cointegration test without Structural breaks

\begin{tabular}{|c|c|c|c|c|}
\hline Cointegrating Vectors & $\begin{array}{r}\text { Trace } \\
\text { statistic }\end{array}$ & $5 \% \mathrm{CV}$ & $\begin{array}{l}\text { Max-Eigen } \\
\text { statistic }\end{array}$ & $5 \% \mathrm{CV}$ \\
\hline$r=0$ & 46.46045 & 47.85613 & 24.07610 & 27.58434 \\
\hline$r \leq 1$ & 22.38435 & 29.79707 & 13.31184 & 21.13162 \\
\hline $\mathrm{r} \leq 2$ & 9.072507 & 15.49471 & 9.064964 & 14.26460 \\
\hline $\mathrm{r} \leq 3$ & 0.007542 & 3.841466 & 0.007542 & 3.841466 \\
\hline Decision: & \multicolumn{2}{|c|}{ No long-run relationship } & \multicolumn{2}{|c|}{ No long-run relationship } \\
\hline
\end{tabular}

Table 7. Hatemi-J Threshold cointegration test with structural break

\begin{tabular}{lccc}
\hline $\ln I N D=f(\ln R E P, \ln N R E P):$ & $A D F^{*}$ & $Z \alpha^{*}$ & $Z_{i}^{*}$ \\
\hline $\mathrm{C}$ & $-5.65663(0.8,0.18)$ & $-4.29242(0.7,0.18)$ & $-4.292420(0.7,0.18)$ \\
$\mathrm{C} / \mathrm{T}$ & $-6.14034(0.8,0.15)$ & $-3.28736(0.6,0.14)$ & $-3.287369(0.6,0.14)$ \\
$\mathrm{C} / \mathrm{S}$ & - & - & \\
& $6.45808(0.15,0.21)$ & $6.42757(0.14,0.21)$ & $-6.45808(0.15,0.21)$
\end{tabular}


Note: The critical values are provided in Hatemi-J (2008, pp 501). The cointegration test includes level of shift (C), level shift with trend $(C / T)$ and regime shift $(C / S)$. The number in parenthesis represents break points.

\subsection{Impulse response to structural shock}

Looking at the impact of changes in electricity production on industrial and agricultural output growths, the study used impulse response analysis to estimate the effects of shocks coming from renewable and non-renewable electricity production on industrial and agricultural output growth. Figure 3 shows the response of the sectoral output variables to structural shocks across 10 periods. The dotted lines represent two standard error bands.

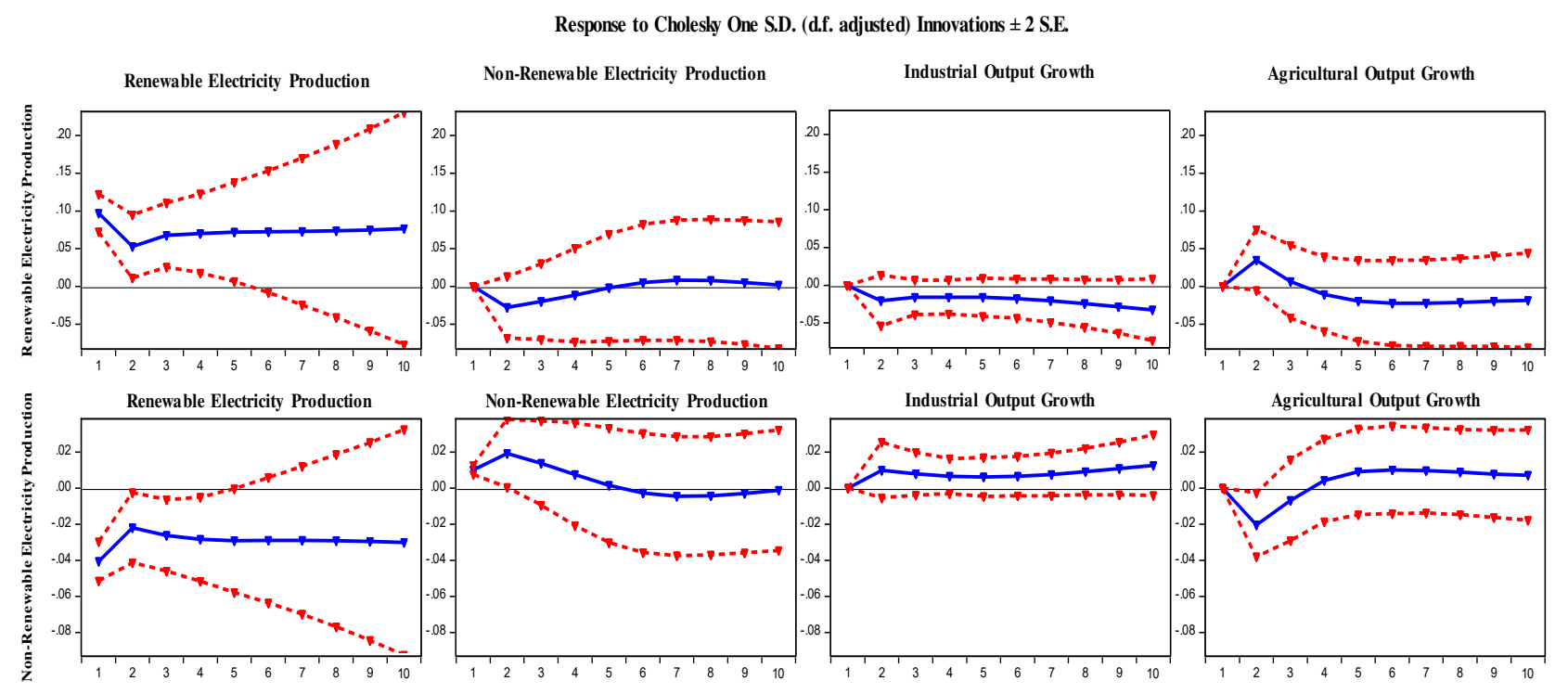

Figure 3: The Impulse response of the dynamic impact of renewable electricity production and non-renewable electricity production on sectoral output growth in Nigeria. Note: the dotted line represents two-standard error bands derived from the structural VAR model described in this paper. Standard errors for the impose responses are calculated with the analytic (Asymptotic) approach.

In addition, Figure 3 shows that shocks to renewable electricity production have a negative impact on industrial output growth over the time horizon. This impact is less pronounced since the values are close to zero. In contrast, shocks to non-renewable electricity production have a positive impact on industrial output growth and remain positive throughout all horizons. However, despite the immediate increase in industrial output, the results show that both shocks to renewable and non-renewable electricity production have a marginal impact on industrial output growth. On the other hand, shocks to renewable electricity production have an asymmetric impact on agricultural output growth within the period. The response increases sharply in the positive region and decreases from the positive to negative regions and remains flat in the long run. Hence, since the values are close to zero, renewable electricity production has a marginal impact on agricultural output growth.

Similarly, shocks to non-renewable electricity production have asymmetric impacts on agriculture output growth within the period. The response decreases sharply at the initial period in the negative region and increases from the negative regions to the positive regions. This impact is also marginal since the values are close to zero. The main conclusion that can be drawn from these results is that electricity production from renewable and non-renewable energy sources contributes slightly to the growth of the industrial and agricultural sectors in Nigeria.

\subsection{Variance decomposition analysis}

This section examines the contribution of different structural shocks to the fluctuations of the industrial and agricultural output growth by estimating the variance decomposition of the forecast error. Table 8 shows the share of the fluctuations of the industrial and agricultural output growth, caused by their own shock compared with the shocks of the other variables. The value in parentheses represents the t-statistics.

The first panel shows that a shock to renewable electricity production accounts for about $25 \%$ fluctuations in industrial output growth in the short run, but decreases to $20 \%$ in the long run. On the other hand, in the initial period, a shock to non-renewable electricity production accounts for $20 \%$ fluctuations in the industrial output growth and the fluctuation increases to $26 \%$ in the long run. These results suggest that the contribution of non-renewable 
electricity production to industrial output fluctuations is slightly more substantial than the contribution of renewable electricity production in Nigeria. However, the contributions in terms of percentages are marginal since they are far from $100 \%$.

In the same vein, a shock to renewable electricity production accounts for $16 \%$ fluctuations in agricultural output growth in the short run but increased to $50 \%$ in the long run. On the other hand, a shock to non-renewable electricity production accounts for $16 \%$ fluctuations in agricultural output growth and the fluctuations slightly decrease to $14 \%$ in the long run. These results show that the contribution of renewable electricity production to agricultural output fluctuations is more substantial compare to the case of renewable electricity production. However, the contributions in terms of percentages are marginal since they are far from $100 \%$.

Overall, the results imply that electricity production from renewable and non-renewable energy sources are not the major determinant of growth in the industrial and agricultural sectors. These findings disagree with those of Salim et al. (2014), who found that non-renewable energy consumption is a major determinant of industrial output in both the short- and long-run in OECD countries.

Table 8. Variance Decomposition of $\ln I N D$ and $\ln A G R$ :

\begin{tabular}{|c|c|c|c|c|c|}
\hline \multirow[b]{2}{*}{ Month } & \multicolumn{4}{|c|}{ Decomposition of lnIND: } & \multirow[b]{2}{*}{ LNAGR } \\
\hline & S.E. & LNREP & LNNREP & LNIND & \\
\hline \multirow[t]{2}{*}{1} & 0.035098 & 17.64072 & 2.717923 & 79.64135 & 0.000000 \\
\hline & & $(12.0430)$ & $(6.12018)$ & $(12.5464)$ & $(0.00000)$ \\
\hline \multirow[t]{2}{*}{3} & 0.068795 & 25.75247 & 20.50470 & 52.01525 & 1.727585 \\
\hline & & $(14.1814)$ & $(13.7077)$ & $(14.4089)$ & $(5.44905)$ \\
\hline \multirow[t]{2}{*}{6} & 0.102522 & 24.71839 & 24.00335 & 49.93581 & 1.342450 \\
\hline & & $(16.8885)$ & $(17.7635)$ & $(18.6240)$ & $(7.22763)$ \\
\hline \multirow[t]{2}{*}{9} & 0.127635 & 22.45059 & 26.05033 & 50.50818 & 0.990905 \\
\hline & & $(19.7666)$ & $(19.3057)$ & $(21.4825)$ & $(8.21146)$ \\
\hline \multirow[t]{3}{*}{12} & 0.148757 & 20.41360 & 26.93285 & 51.88437 & 0.769188 \\
\hline & & $(22.4360)$ & $(19.6694)$ & $(23.0636)$ & $(8.91306)$ \\
\hline & \multicolumn{4}{|c|}{ Decomposition of lnAGR: } & \\
\hline Month & S.E. & LNREP & LNNREP & LNIND & LNAGR \\
\hline \multirow[t]{2}{*}{1} & 0.077093 & 2.126300 & 16.03735 & 1.174416 & 80.66193 \\
\hline & & $(6.27090)$ & $(11.3717)$ & $(4.61279)$ & $(12.3524)$ \\
\hline \multirow[t]{2}{*}{3} & 0.094216 & 16.40503 & 14.26794 & 3.945309 & 65.38172 \\
\hline & & $(12.4234)$ & $(11.2412)$ & $(5.80874)$ & $(14.0444)$ \\
\hline \multirow[t]{2}{*}{6} & 0.113729 & 36.56568 & 11.50965 & 6.699592 & 45.22508 \\
\hline & & $(17.2554)$ & $(12.2004)$ & $(6.09345)$ & $(14.5837)$ \\
\hline \multirow[t]{2}{*}{9} & 0.132274 & 44.75839 & 12.90255 & 7.782013 & 34.55705 \\
\hline & & $(20.4397)$ & $(14.3666)$ & $(7.27418)$ & $(15.1535)$ \\
\hline \multirow[t]{2}{*}{12} & 0.147234 & 50.21408 & 13.54462 & 7.760414 & 28.48088 \\
\hline & & $(22.5897)$ & $(15.7973)$ & $(8.41341)$ & $(15.2136)$ \\
\hline
\end{tabular}

Cholesky Ordering: lnREP lnNREP lnIND lnAGR. Standard Errors: Monte Carlo simulation (1000 replication).

\subsection{Granger causality analysis}

Granger causality tests were performed to investigate the causal relationship among renewable electricity production, non-renewable electricity production, industrial output, and agricultural output. The results are shown in Table 10: there is a strong bidirectional causality between renewable electricity production and industrial output $(\operatorname{lnREP} \leftrightarrow \ln I N D)$. In addition, there is a strong bidirectional causality between non-renewable electricity production and industrial output (lnNREP $\leftrightarrow \operatorname{lnIND})$.

A strong unidirectional causal relationship runs from agricultural output to non-renewable electricity production $(\ln A G R \rightarrow \ln N R E P)$; a unidirectional causality runs from agricultural output to renewable electricity production $(\ln A G R \rightarrow \ln R E P)$. For other variables, there is a bidirectional causal relationship between renewable and nonrenewable electricity production ( $\operatorname{lnREP} \leftrightarrow \operatorname{lnNREP}$ ) and a weak unidirectional causal relationship running from industrial output to agricultural output $(\ln I N D \rightarrow \ln A G R)$. 
Table 9. SVAR Granger Causality/Block Exogeneity Wald Tests

\begin{tabular}{|c|c|c|c|c|}
\hline & \multicolumn{4}{|c|}{ Dependent variable } \\
\hline & $\operatorname{lnREP}$ & $\operatorname{lnNREP}$ & $\operatorname{lnIND}$ & $\ln A G R$ \\
\hline lnREP does not cause & - & $10.96291^{* * *}$ & $19.39796^{* * * *}$ & 1.849338 \\
\hline lnNREP does not cause & $12.06802^{* * * *}$ & - & $17.60629 * * *$ & 1.735077 \\
\hline lnIND does not cause & $14.27558^{* * * *}$ & $13.1057^{* * *} *$ & - & $7.145431^{*}$ \\
\hline lnAGR does not cause & $10.03156^{* *}$ & $14.05939^{* * * *}$ & 2.097744 & - \\
\hline All & $57.94412^{* * * *}$ & $48.24437 * * *$ & $33.14876^{* * * *}$ & 8.068812 \\
\hline
\end{tabular}

Notes: "All" means the Granger causality test set for all independent variables. Wald tests are based on the $\chi^{2}$ statistic, with $3 \mathrm{df}$, except for "All”, $9 \mathrm{df}$. ${ }^{*}$ denotes significance at $10 \%$, ** denotes significance at $5 \%$, respectively, *** denotes significance at $1 \%$.

In short, the empirical results provide evidence that supports the feedback hypothesis between renewable electricity production and industrial output; and between non-renewable electricity production and industrial output; The results also provide evidence in support of the conservation hypothesis between agricultural output and nonrenewable electricity production; and between agricultural output and renewable electricity production.

Overall, the results validate the theoretical basis for using the SVAR model (i.e. the block exogeneity confirms the endogeneity of all variables). These findings are in line with several studies (see e.g. Jebli and Youseff, 2015; Salim et al 2014, Marques et al. , 2014, Apergis and Payne, 2011, Al-mulali et al, 2013).

Table 10. Summary of the direction of causality

\begin{tabular}{ll}
\hline IND and REP & Feedback hypothesis \\
IND and NREP & Feedback hypothesis \\
AGR and REP & Conservation hypothesis \\
AGR and NREP & Conservation hypothesis \\
\hline
\end{tabular}

\subsection{Robustness Analysis}

This section assesses the validity of the estimated SVAR model. The section comprises SVAR diagnostic tests, estimated coefficients of A and B matrices and SVAR lags order selection criteria. Table 11 shows the results of normality, autocorrelation, and heteroskedasticity. The results prove the evidence of normality both for the individual components and the components considered jointly. The results also fail to reject the null hypothesis of no serial correlation. For the white test, the result strongly shows non-rejection of the null hypothesis of homoskedaticity at the $10 \%$ level of significance $(p-v a l u e=0.185)$

\section{Table 11}

SVAR Diagnostic tests.

\begin{tabular}{|c|c|c|c|c|c|c|c|}
\hline \multicolumn{6}{|c|}{ Normality tests } & \multicolumn{2}{|c|}{ Autocorrelation LM test } \\
\hline $\operatorname{lnREP}$ & -0.115309 & 0.066481 & 2.890789 & 0.014909 & 0.081389 & 1 & 15.05675 \\
\hline $\operatorname{lnIND}$ & 0.435776 & 0.949502 & 3.330203 & 0.136293 & 1.085795 & 3 & 15.5324 \\
\hline $\ln A G R$ & 0.598224 & 1.789358 & 4.729412 & 3.738581 & 5.527939 & 4 & 14.79516 \\
\hline
\end{tabular}

**** Denotes $1 \%$ level of significance

Table 12

SVAR Lag Order Selection Criteria

\begin{tabular}{ccccccc}
\hline Lag & LogL & LR & FPE & AIC & SC & HQ \\
\hline 0 & 120.7936 & NA & $4.88 \mathrm{E}-09$ & -7.786239 & -7.59941 & -7.72647 \\
1 & 231.3236 & 184.2166 & $9.06 \mathrm{E}-12$ & -14.08824 & $-13.15411^{* *}$ & -13.7894 \\
2 & 254.5715 & 32.54713 & $5.96 \mathrm{E}-12$ & -14.57144 & -12.89 & -14.0335 \\
3 & 283.5881 & $32.88548^{* *}$ & $2.96 \mathrm{e}-12^{* *}$ & $-15.43921^{* *}$ & -13.0105 & $-14.66223^{* *}$ \\
\hline
\end{tabular}


** Indicates lag order selected by the criterion. LR: sequential modified LR test statistic (each test at $5 \%$ level). FPE: Final prediction error, AIC: Akaike information criterion, SC: Schwarz information criterion and HQ: Hannan-Quinn information criterion

The number of lags for the SVAR model was chosen according to the lag length criterion tests. LR test statistic, Final Prediction Error (FPE), Hannan-Quinn Information Criterion and Akaike info criterion (AIC) and LM test suggest three lags since the null hypothesis of no serial correlation was accepted at lags 3. The estimated matrices A and $\mathrm{B}$ show the contemporaneous structural parameters of the dynamic relationship between renewable electricity production, non-renewable electricity production, industrial output and agricultural output which determines the instantaneous relationship among the elements of the variables and the elements of the structural shock contained in the disturbance term of each variable. The values in parenthesis are probability values of the estimated matrices A and B. It was shown that all the structural shocks are highly significant.

Estimated coefficients of A and B matrices using the AB model approach suggested by Amisano and Giannini (1997).

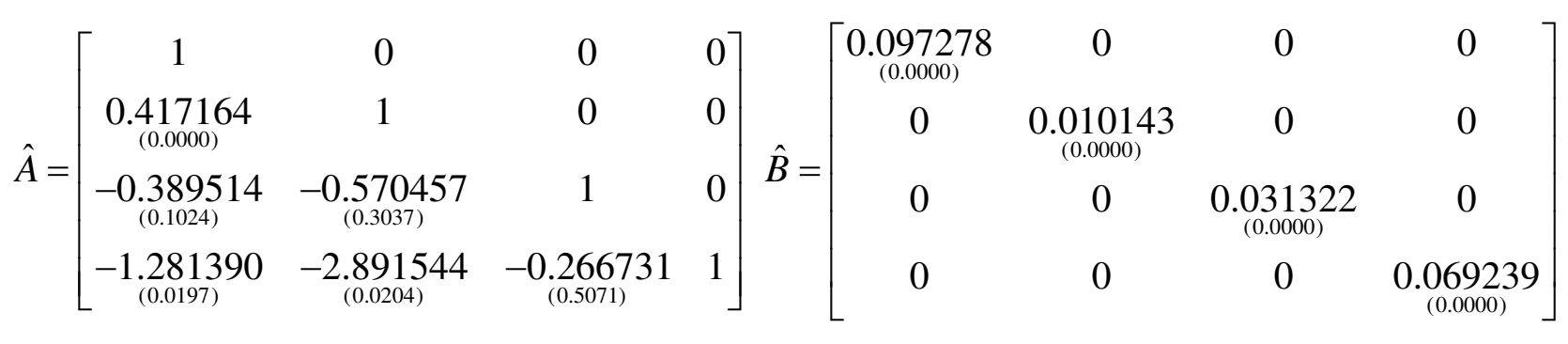

\section{Conclusions and policy implications}

This study sought to empirically investigate the dynamic effects of electricity production from renewable and nonrenewable energy sources on industrial and agricultural output growth in Nigeria. The analysis shows that policy changes in the Nigerian energy sector, which are captured by shocks to renewable and non-renewable electricity production are slightly consequential to the growth of the industrial and agricultural sectors. Specifically, shocks to renewable and non-renewable electricity production on average account for about $22 \%$ and $20 \%$ of the fluctuations in industrial output growth respectively. Likewise, shocks to renewable and non-renewable electricity production on average account for about $30 \%$ and $14 \%$ of the fluctuations in the agricultural output growth.

More importantly, the granger causality supports the existing claim that economic growth and energy are linked. Particularly, the analysis shows a bidirectional causality between industrial output and renewable electricity production, likewise, between industrial output and non-renewable electricity production. These results disprove the existence of the neutrality hypothesis but support the feedback hypothesis. On the other hand, there is a unidirectional causality running from agricultural output to renewable and non-renewable electricity production, which supports the conservation hypothesis. Overall, these results imply that in spite of the importance of energy to the growth of the Nigerian economy, the Nigerian energy sector has a marginal impact on the growth of the industrial and agricultural sectors.

The evidence provided in this paper explains the current challenges faced by industries operating in Nigeria due to a lack of on-grid power supply. As reported in January 2020, losses to Nigeria's electricity sector reached 25.77billion naira due to poor distribution and transmission facilities, inadequate gas, among other factors. ${ }^{1}$ Hence, as the shortage of the supply of electricity remains an impediment to doing business in the country, the government should diversify electricity production across the potential energy sources. One of the possibilities the government could explore is to invest in off-grid and mini-grid electricity projects. In addition, the following are also necessary: prioritization of policies for the development of the energy sector; eradication of mismanagement and lack of monitoring; and acceleration of projects under the NESP.

Further research could take several directions. Firstly, it would be interesting to investigate the sectoral impact of off-grid and on-grid electricity production in Nigeria. Disentangling electricity production into off-grid and on-grid will show which of the two contribute the most to the growth of the Nigerian industries. Secondly, it would be interesting to incorporate in this study the factors of political instability and mismanagement, to see if these two institutional problems could explain the shocks to renewable and non-renewable electricity production.

1 https://www.vanguardngr.com/2020/01/state-of-nigerias-electricity-sector-worsens-investigation/ 
Ackah, I., (2015). On the relationship between energy consumption productivity and economic growth. Munich Personal RePEc Archive, 64887.

Akinlo, A.E, (2009). Electricity consumption and economic growth in Nigeria: Evidence from cointegration and cofeature analysis. Journal of Policy Modelling 31, 681-693.

All Africa, (2012). Nigeria: Coal as a potential source of energy, allafrica.com/stories/201201240981.html

Al-mulali, U., Fereidouni, H.G, Lee, J.Y.M, (2014). Electricity consumption from renewable and non-renewable energy sources and economic growth: Evidence from Latin American countries. Renewable and Sustainable Energy Reviews 30, 290-298.

Alper, A., Oguz, O., (2016). The role of renewable energy consumption in economic growth: Evidence from asymmetric causality. Renewable and Sustainable Energy Reviews 60, 953-959.

Amisano, G., Giannini, C., (1997). Topics in Structural VAR Econometrics (second edition).

Apergis, N., Payne, J.E., (2011). A dynamic panel study of economic development and the electricity consumptiongrowth nexus. Energy Economics 33, 770-781

Atems, Bebonchu, and Chelsea Hotaling., (2018). The effect of renewable and nonrenewable electricity generation on economic growth. Energy Policy 112 (): 111-118.

Beliad, F., Abderrahmani, F., (2013).Electricity consumption and economic growth in Algeria: A multivariate causal analysis in the presence of structural change. Energy Policy 55, 286-295.

Bozkurt, C. Destek, M.A, (2015). Renewable energy and sustainable development nexus in selected OECD countries. International Journal of Energy Economic and Policy, 5(2), 507-514.

Central Bank of Nigeria (CBN) 2015. Online Database.

Cerdeira Bento, J.P, Moutinho, V., (2016). $\mathrm{CO}_{2}$ emissions, non-renewable and renewable electricity production, economic growth, and International trade in Italy. Renewable and Sustainable Energy Reviews 55, 142-155.

Depuru, S.S.S.R., Wang, L. and Devabhaktuni, V., (2011). Electricity theft: Overview, issues, prevention and a smart meter based approach to control theft. Energy Policy, 39(2), pp.1007-1015.

Dickey, D.A., Fuller, W.A., (1979). Distribution of the estimators for autoregressive time series with a unit root. Journal of American Statistical Association. 74, 427-431.

Dogan, E., (2015). The relationship between economic growth and electricity consumption from renewable and nonrenewable sources: A study of Turkey. Renewable and Sustainable Energy Reviews 52, 534-546.

The Emissions and Generation Resource Integrated Database (eGDRID), (2013). Energy and the Environment, 2013, United States (US).

Engle, R.F., Granger, C.W.J., (1987). Cointegration and error correction: representation, estimation and testing. Econometrica 55, 251-276.

Frynas, J.G., (1999). Oil in Nigeria; Conflit and litigation between oil companies and village communities. Munster, Hamburg and London: Lit Verlag 1999. Pp 263.

Fuinhas, J.A, Marques, A.C, (2012). Energy consumption and economic growth nexus in Portugal, Italy, Greece, Spain and Turkey: An ARDL bounds test approach (1965-2009). Energy Economic 34, 51 1-517.

Granger, C. W. J., Yoon, G., (2002). Hidden cointegration, Working Paper, No. 2002-02, Department of Economics, University of California, San Diego, CA.

Hamdi, H., Sbia, R.,Shahbaz, M., (2014). The nexus between electricity consumption and economic growth in Bahrain. Economic Modelling 38, 227-237.

Hatemi-J, A., (2008). Tests for cointegration with two unknown regime shifts with an application to financial market integration. Empirical Economics 35 (3), 497-505.

Ibrahiem, D.M, (2015). Renewable electricity consumption, foreign direct investment and economic growth in Egypt: An ARDL approach. Procedia Economics and Finance 30, 313-323.

Iyke, B.N, (2015). Electricity consumption and economic growth in Nigeria: A revisit of the energy-growth debate. Energy Economics 51,166-176.

Jamil, F., (2013). On the electricity shortage, price and electricity theft nexus. Energy Policy, 54, pp.267-272.

Jebli, M.B., Youssef, S.B., (2015). Output, renewable and non-renewable energy consumption and international trade: Evidence from a panel of 69 countries. Renewable Energy 83, 799-808.

Johansen, S., Juselius, K., (1990). Maximum likelihood estimation and inference on cointegration: with application to the demand for money. Oxford Bulletin of Economic Statistics. 52, 169-210.

Karanfil, F., Li, Y., (2015). Electricity consumption and economic growth: Exploring panel-specific differences. Energy Policy 82, 264-277.

Kim, Y.S., (2015). Electricity consumption and economic development: Are countries converging to common trends?. Energy Economics 49, 192-202.

Kraft, J., Kraft, A., (1978). On the Relationship Between Energy and GNP: Journal of Energy Development, 3, 401-403.

Maji, I.K., Sulaiman, C. and Abdul-Rahim, A.S., (2019). Renewable energy consumption and economic growth nexus: A fresh evidence from West Africa. Energy Reports, 5, pp.384-392.

Marques, A.C, Fuinhas, J.A, (2015). The role of Portuguese electricity generation regimes and industrial production. Renewable and Sustainable Energy Reviews 43, 321-330.

Marques, A.C, Fuinhas, J.A, Menegaki, A.N, (2014). Interactions between electricity generation sources and economic activity in Greece: A VECM approach. Applied Energy 132, 34-46. 
Nathaniel, S. P., \& Bekun, F. V. (2020). Electricity consumption, urbanization, and economic growth in Nigeria: New insights from combined cointegration amidst structural breaks. Journal of Public Affairs, e2 102.

National Renewable Energy and Energy Efficiency Policy (NREEP), (2015). The electricity sector, Ministry of Power, Nigeria.

National Bureau of Statistics (2010): National Manpower Stock and Employment Generation Survey, Household and Micro Enterprise-July 2010. file:///Users/imisiaiyetan/Downloads/Labour\%20Force\%20Statistics,\%202010.pdf

Odugbesan, J. A., \& Rjoub, H. (2020). Relationship Among Economic Growth, Energy Consumption, CO2 Emission, and Urbanization: Evidence From MINT Countries. SAGE Open, 10(2), 2158244020914648.

Ohler, A., Fetters, I, (2014). The causal relationship between renewable electricity generation and GDP growth: A study of energy sources. Energy Economics 43, 125-139.

Olayeni, O.R, (2012). Energy consumption and economic growth in sub-Saharan Africa: An Asymmetric Cointegration Analysis. International Economic 129, 99-118.

Pesaran M H, ShinY., Smit, J. (2001). Bounds testing approaches to the analysis of level relationships. Journal of Applied Economics; 16:289-326.

Phillips P, Hansen, B., (1990). Statistical inference in instrumental variables regression with I (1) process. Rev Econ Stud 1990; 57:99-125.

Tiwari, A.K, Apergis, N., Olayeni, O.R, (2014). Renewable and non-renewable energy production and economic growth in sub-Saharan Africa: A hidden cointegration analysis. Applied Economics, DOI:10.1080/00036846.2014.982855.

Salahuddin, M., Alam, K., (2015). Internet usage, electricity consumption and economic growth: A time series evidence. Telematics and Informatics 32, 862-878.

Salim, R.A, Hassan, K., Shafiei, S., (2014). Renewable and non-renewable energy consumption and economic growth: Further evidence from OECD countries. Energy Economic 44, 350-360.

Schorderet, Y., (2004). Asymmetric cointegration, Working Paper, No. 2004-23, University of Geneva, Geneva.

Tang, C.F, Tan, B.W, Oztruk, I., (2016). Energy consumption and economic growth in Vietnam. Renewable and Sustainable Energy Reviews 54, 1506-1514.

Wolde-Rufael, Y., (2014). Electricity consumption and economic growth in transition countries: A revisit using bootstrap panel Granger causality analysis. Energy Economics 44, 325-330.

World Coal Institute, (2003). The Coal Resource, (An overview of coal), http://www.worldcoal.org.

World development indicators, (2015) CD-ROM. Washington DC, USA: World Bank.

Zivot E, Andrews D. (1992). Further evidence of the great crash, the oil price shock and the unit root hypothesis. Journal of Business and Economic Statistical; 10(3): 251-70 